NBER WORKING PAPER SERIES

\title{
PRODUCT SWITCHING AND THE BUSINESS CYCLE
}

\author{
Andrew B. Bernard \\ Toshihiro Okubo \\ Working Paper 22649 \\ http://www.nber.org/papers/w22649 \\ NATIONAL BUREAU OF ECONOMIC RESEARCH \\ 1050 Massachusetts Avenue \\ Cambridge, MA 02138 \\ September 2016
}

This study is conducted as a part of the Project "Restoration from Earthquake Damage and Growth Strategies of the Japanese Regional Economy" undertaken at Research Institute of Economy, Trade and Industry (RIETI). Utilized data is micro-data pertaining to the Census of Manufacturers (Kogyou Tokei Chosa) conducted by Ministry of Economy, Trade and Industry. The authors are grateful for helpful comments and suggestions by seminar participants at RIETI. The views expressed herein are those of the authors and do not necessarily reflect the views of the National Bureau of Economic Research.

NBER working papers are circulated for discussion and comment purposes. They have not been peer-reviewed or been subject to the review by the NBER Board of Directors that accompanies official NBER publications.

(C) 2016 by Andrew B. Bernard and Toshihiro Okubo. All rights reserved. Short sections of text, not to exceed two paragraphs, may be quoted without explicit permission provided that full credit, including $\left({ }^{\circ}\right.$ notice, is given to the source. 
Product Switching and the Business Cycle

Andrew B. Bernard and Toshihiro Okubo

NBER Working Paper No. 22649

September 2016

JEL No. E32,L11,L21,L25,L60

\section{ABSTRACT}

This paper explores role of product adding and dropping within manufacturing firms over the business cycle. While a substantial body of work has explored the importance of the extensive margins of firm entry and exit in employment and output flows, only recently has research begun to examine the adjustment across products within firms and its importance for firm and aggregate output and employment flows. Using a novel, annual firm-product data set covering all Japanese manufacturing firms with more than 4 employees from 1992 to 2006, we provide the first evidence on annual changes in product adding and dropping by continuing firms over the business cycle. We find very high rates of product adding and dropping by continuing firms between the last year of the recession and the first year of the subsequent expansion and offer an explanation and supporting evidence based on a "trapped factors" model of firm behavior.

Andrew B. Bernard

Tuck School of Business at Dartmouth

100 Tuck Hall

Hanover, NH 03755

and CEPR

and also NBER

Andrew.B.Bernard@dartmouth.edu

Toshihiro Okubo

Keio University

2-15-45 Mita Minato-ku

Tokyo Japan

okubo@econ.keio.ac.jp 


\section{Introduction}

This paper explores the importance of product adding and dropping within manufacturing firms over the business cycle. While recessions have long been associated with declines in output and increased firm exit, we show that recessions are times of substantial changes in output mix for continuing firms. Product switching is strongly countercyclical with add and drop rates increasing by more than a third in recessions. In addition, firms are most likely to be both adding and dropping products around recession troughs.

This paper documents the mix and evolution of firms and products in the Japanese manufacturing sector from 1992-2006. The study provides evidence on the product mix at Japanese manufacturing firms and the role of product switching in the evolution of aggregate output. The period covered by the firm-product data includes three substantial recessions, a decline in manufacturing as a share of GDP and an equally sharp reduction in manufacturing employment as a share of total employment.

Every year Japanese manufacturing firms engage in a substantial amount of product switching, i.e. adding and/or dropping products from their output mix. Twenty percent of all firms change their product mix each year by adding and/or dropping one or more products. For multi-product firms that account for more than three quarters of manufacturing output, product mix changes are even more prevalent and occur primarily by churning, i.e. simultaneously adding and dropping products. During transitions from recession to expansion, firm-level product churning increases by 25 percent. Changes in industry and sector mix show comparable increases during recession transitions.

This increase in product mix changes around recessions is not systematically related to the rise and decline of particular products. Firms do not seem to be leaving some products and entering others; 77 percent of products have higher drop rates and higher add rates during recessions. Furthermore, products with the greatest sunk costs are more likely to be both added and dropped in recessions. For the average product, recessions are times of reallocation across producers. Continuing firms that introduce the product account for a 50 percent larger share of product output while previous producers and new firms have smaller output shares. Within firms, added products are relatively more important during recessions, contributing 50 percent more to the firm's overall production.

The contribution of exiting and entering firms to aggregate output changes is small compared to the contribution of within-firm product adding and dropping in all years. This is especially true during recession transitions when the contributions of product additions by surviving firms are three times as large as those of new firms, while product drops by continuers are more than 2.5 times larger than exiting firm contributions. 
To explain the cyclical nature of product changes, we appeal to recent theoretical work on "trapped factors" by Bloom et al.(2013, 2014). In this theory, large, negative demand shocks reduce output at the firms and leave some production workers underemployed. Since these workers cannot easily be released from employment, the firm uses them to engage in innovation activities. For an economy such as Japan's with a history of lifetime employment, recessions are a time when many firms may face lower opportunity costs of new product development. This leads to increased product dropping (negative demand shocks) and increased product adding (increased innovation) during recessions. We explore the implications of the "trapped factors" model in our data and find some tentative support.

This paper is related to several new streams of research on the internal allocation of resources at firms. Bernard et al. (2010) document the prevalence of multi-product firms and the frequency of product switching over five-year intervals in the US manufacturing sector. They find that a large fraction of surviving firms switch their product mix and that product switching activity within firms is an important component of industrial evolution. Kawakami and Miyagawa (2010) examine product switching in Japanese firms over multi-year intervals and find similar results to Bernard et al. (2010). A number of papers examine multi-product firms and product switching in the context of international trade and exporting, e.g. Bernard et al. (2011), ?Goldberg et al. (2010), and Iacovone and Javorcik (2010). We are able to examine annual product switching behavior by Japanese manufacturing firms over a longer span of years and focus on the variation over the business cycle.

Most of the literature on firm dynamics has focused on the effects of entry and exit behavior on productivity growth at the firm and industry levels, see Baily et al. (1992), Dunne et al. (1989a), Dunne et al. (1989b), and Foster et al. (2006). Nishimura et al. (2005) and Fukao and Kwon (2006) examined the effects of entry and exit behavior on productivity growth at both the firm and industry levels in Japan. They find that the major factor affecting productivity growth is within firm changes rather than entry and exit. Our paper also links to work on the sources of the reduction in Japanese output and productivity growth starting in the early 1990s, e.g. Caballero et al. (2008). We find that while the overall number of Japanese manufacturing firms was shrinking rapidly, this decline was concentrated in smaller, single-establishment enterprises. In contrast, the surviving, typically larger, firms were actively adjusting their product mix, especially during the three recessions.

The next section describes the data including our definition of a product, industry and sector. Section 3 documents the extent and evolution of single and multi-product firms in Japanese manufacturing. In Section 4 we look at multi-product firms and their product adding and dropping activities. Section 5 quantifies the contribution of new firms and new products at continuing firms to product sales and examines the contribution of added and dropped products to firm output. We look at the aggregate implications of product adding and dropping in Section 6 by calculating the extensive and intensive margin contributions to aggregate manufacturing growth. Section 7 
Table 1: Sectors, Industries and Products - An Example

\begin{tabular}{|l|l|}
\hline Product & Description \\
\hline 25 & General Machinery \\
2523 & Oil hydraulic and pneumatic equipment \\
252311 & Hydraulic pumps \\
252312 & Hydraulic motors \\
252313 & Hydraulic cylinders \\
252314 & Hydraulic valves \\
252319 & Miscellaneous oil hydraulic equipment \\
252321 & Parts, attachments and accessories of hydraulic equipment \\
252331 & Pneumatic equipment, including pneumatic unit equipment \\
252332 & Parts, attachments and accessories of pneumatic equipment \\
252391 & Hydraulic and pneumatic equipment, parts, attachments and accessories (piecework) \\
\hline
\end{tabular}

evaluates potential theoretical explanations for the findings while the final section concludes.

\section{Data}

The data is taken from Japan's Census of Manufactures (Kogyo Tokei Chosa in Japanese) prepared by METI (Ministry of Economy, Trade and Industry). The data covers all establishments with four or more regular employees in each year in every manufacturing industry. Manufacturing establishments are categorized as one of two types: single-establishment firms (SE) and multi-establishment firms (ME). ME firms are comprised of two or more manufacturing plants, each of which has four or more regular employees.

In the original survey data, these establishments do not have common identification numbers over time. By using the Establishment Master database ("Kogyotokei Converter") prepared by RIETI (Research Institute for Economy, Trade and Industry), we can assign plants a common identification number across years. In addition, the original survey data does not contain firm identifiers to allow multi-establishment (ME) plants to be grouped into firms. Using Firm Master database ("Kigyo Masuta") prepared by METI and the "Basic Survey of Japanese Business Structure and Activity", which is a firm-level survey data, we create consistent firm identification numbers and aggregate ME plants into a single firm. As a result we have information on the number of establishments in a firm and can categorize firms as single-establishment (SE) or multi-establishment (ME).

In addition to the standard firm-level data collected in manufacturing surveys, i.e. the value of total output and inputs, there is information on the value of production output for individual products on an annual basis. This disaggregated output information for each firm is available for six digit products according to the Japanese Standard Industrial Classification 11 Table 1 gives an

\footnotetext{
${ }^{1} \mathrm{An}$ english language description of two-digit sectors and four-digit industries is available at http://www.stat.go.jp/english/index/seido/sangyo/san07-3a.htm\#e
} 
example of six-digit JSIC products within the General Machinery sector (23). There are 9 six-digit products within the Oil Hydraulic and Pneumatic Equipment industry (2523). As is often the case with definitions in manufacturing surveys, these "products" are themselves aggregates of more differentiated goods. Table 2 reports the number of four digit industries and six digit products for every manufacturing sector. There are 531 industries and 2060 products in the 24 manufacturing sectors. The numbers of products per industry varies across sectors from a high of 5.9 in Production Machinery (26) to a low of 1.9 in Electronic Parts, Devices and Circuits (28).

We focus on the longitudinal firm and product data from recent surveys available from 1992 to 2006. Our sample ends in 2006 because of a substantial change in the definition of output starting in 2007 2 One issue with the data from the Annual Survey of Manufacturers involves changes in six-digit product classifications due to revisions in the JSIC. We use concordance tables available in the survey and the methodology developed by Pierce and Schott $(2012)$ to create consistent six digit product classification changes over time. The product data allows us to determine the product mix and output levels for each firm in each year.

\section{Multi-Product Firms Over Time}

In this section we begin to explore the firm-product data for Japan. Table 3 reports the number of firms by firm group and product-count category from 1992 to 2006.

\subsection{Evolution over time}

The period 1992 to 2006 was one of substantial macroeconomic turbulence and structural change in Japan. Following decades of rapid growth, Japan experienced a series of recessions and average annual real GDP growth slowed to under $1.4 \%$ per year. As can be seen in Figure 1, this period was the beginning of a secular decline in the importance of manufacturing in overall output and employment. The total number of manufacturing firms declined precipitously (38.5 percent) during the period from 400,749 to 246,564 , and, in fact, fell much faster than the manufacturing shares of GDP and employment, see Table 3 . In spite of their falling numbers, manufacturing firms grew on average over the period. In 1992, it took 16,290 manufacturing firms to produce one percent of Japanese GDP, in 2006, 11,106 firms accounted for the same share of output.

While single establishment (SE) and single-product (SP) firms are the most common in every year, there are significant trends in the types of active establishments over time. The number of SE-SP firms dropped by more than 108,000 from 1992 to 2006, a decline of over 40 percent, while the number of single-establishment, multiple-product (SE-MP) firms fell by 33.3 percent, shifting the composition of firms towards multi-product establishments. Multi-establishment firms fared

\footnotetext{
${ }^{2}$ Starting in 2007, establishment output includes outsourced production whereas prior to 2007 outsourced production was not included. Outsourcing is defined as activity where the final process is performed by other firms.
} 
Figure 1: Manufacturing employment share, 1992-2006

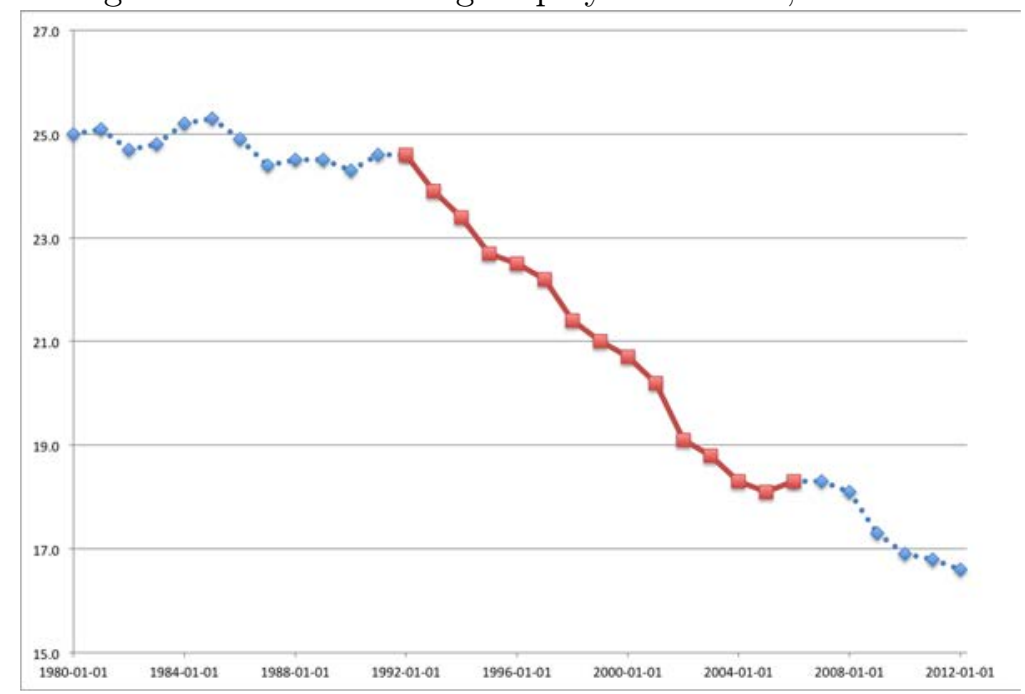

Note: Annual employment share in manufacturing. Solid lines (squares data points) indicates the period of analysis of our data. Source: Federal Reserve Bank of St. Louis FRED data

much better with their numbers essentially unchanged. Output per firm increased for all types of firms, but especially for SE-SP. In this paper, we focus less on the secular decline in manufacturing firms and output share and instead concentrate on the activity of firms over the cycle.

\subsection{Firms, output, and the business cycle}

Figure 2 shows the evolution of industrial production from 1992-2006, with low average annual growth of 0.8 percent per year and three distinct cycles, largely coinciding with recessions and expansions of the overall Japanese economy. The bottom of the three manufacturing output recessions can be dated to January 1994, November 1998 and November 2001. For our purposes, the fact that each of the manufacturing recessions ends very close to the conclusion of the calendar year is fortuitous as we are able to cleanly associate annual firm-product output to years before and after the end of each downturn.

In particular we identify three pairs of years as particularly important in the evolution of product mix decisions by firms. These year-pairs include the last full year of each recession and the first year of the subsequent industrial expansion, 1993-1994, 1998-1999 and 2001-2002. For the remainder of the paper we will refer to these year-pairs as recession years and group all other years together as non-recession years $\mathrm{S}^{3}$

\footnotetext{
${ }^{3}$ We recognize that $1992-1993$ and $2003-2004$ could potentially be substantially different in terms of firm behavior; one covers two years of a downturn and the other covers two years of an expansion. In results available upon request, we show that there is little or no difference between such years in terms of product mix decisions by Japanese manufacturing firms.
} 
Figure 2: Japanese Industrial Production, 1992-2006

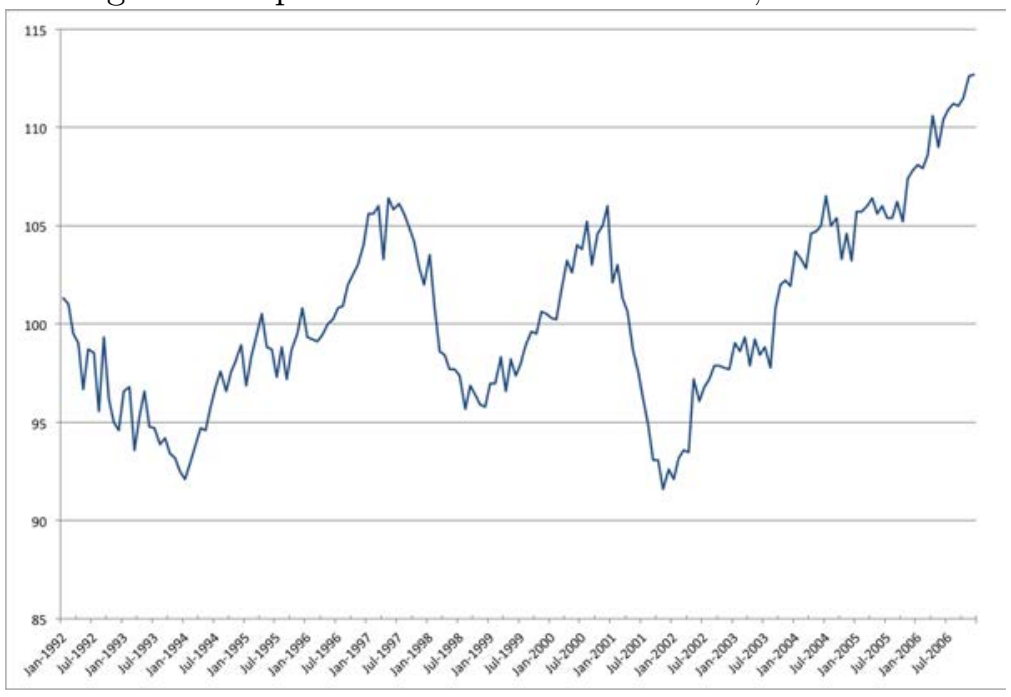

Note: Monthly industrial production index. Output troughs occur in Jan 1994, Nov 1998, and Nov 2001. Source: OECD

In Table 3, we see that the recession years were different both in terms the number of active firms and their output. On average the total number of firms declined by 8.0 percent from the last year of the recession to the first year of the expansion. In other years the decline in firms was 2.2 percent. This reduction in the firm count was particularly large for single-establishment firms. Not surprisingly, overall manufacturing output growth was substantially lower for these three pairs of transition years, declining on average 2.1 percent while rising 1.6 percent in the other years.

The importance of the firm entry-exit margin to total manufacturing output over the business cycle is well-known, e.g. Campbell (1998), and well-documented for Japan and other advanced industrialized countries. However, to date there has been no systematic research on the importance of product-mix adjustments inside the firm. We turn now to examine the explore role of product switching across firms and over time.

\section{Multi-Product Firms and Product Switching}

\subsection{Products per firm}

Table 4 reports the frequency of multi-product, multi-industry and multi-sector firms for all manufacturing firms for 1992 and 2006. Firms producing a single product are by far the most common type but have declined in numbers over time. SP firms account for 64.8 percent manufacturing firms in 1992, but they are far smaller than average and produce under a quarter of manufacturing output in each year. Multi-product firms produce 2.7 products on average in 1992. Among multi-product firms, however, there is substantial variation. Multi-sector firms are more than five times larger 
than single industry, multi-product firms; every 1 percent of firms that are multi-sector accounts for 4.28 percent of output. Comparable ratios for single-industry and multi-industry (single-sector) firms are 0.76 and 1.35 respectively $4^{4}$

\subsection{Products per firm over time}

Over time, the share of multi-product firms is increasing, and within MP firms there is a simultaneous shift towards firms that produce in multiple industries or in multiple sectors, which have greater numbers of products per firm. These two trends result in an increase in the average number of products per firm, rising from 1.59 in 1992 to 1.69 in 2006. Similar trends occur in the number of industries and sectors per firm. In Figure 3 the graphs in the left-hand column show the average number of products, industries and sectors per firm. All three increase relatively steadily across the years.

Within surviving firms, however, the story is quite different. The right-hand column of Figure 3 report the coefficients on year dummies in firm-level regressions of the form,

$$
\ln N_{p t}^{i}=\alpha_{p}+\delta_{t}+\varepsilon_{p t}
$$

where $\ln N_{p t}^{i}$ is the $(\log )$ number of products, industries or sectors $(i)$ at firm $p$ in year $t, \alpha_{p}$ is a firm fixed-effect and $\delta_{t}$ are year dummies. In contrast to the rising average across firms, within surviving firms, the numbers of products, industries and sectors initially increases and then steadily falls after 1997. On average surviving firms have fewer products, industries and sectors in 2006 than they did in 1992. The decline in the share of SP firms is driving the overall increase in products per firm even as surviving firms reduce their product range. However, as we will show, there is substantial reallocation across products within surviving firms during this period.

We do not have direct evidence on the source of these changes in the composition of firms and the within-firm changes in the product range, but this period coincides with a substantial increase in offshore investment by Japanese manufacturing firms, increasing competition from imported products, and a large increase in the export intensity of Japanese manufacturing firms. Models of multi-product exporters such as Bernard et al. (2011); Mayer et al. (2014); Eckel and Neary (2010) predict that reductions in trade costs will lead to both rising exports and a narrowing of product scope to focus on core products. The rise in competition would be expected to lead to an extensive margin adjustment in the number of firms, especially those of lower productivity and output. Similarly the reduction of the number of products would be consistent with increasing specialization in core activities at home accompanied by rising production in foreign affiliates.

\footnotetext{
${ }^{4}$ Comparing to the firm-level results for the US in Bernard et al. (2010), we observe similar patterns: multi-product firms are relatively rare, 39 percent of US manufacturing firms, but disproportionately important in total output (87 percent).
} 
Figure 3: Products, Industries and Sectors per Firm, 1992-2006

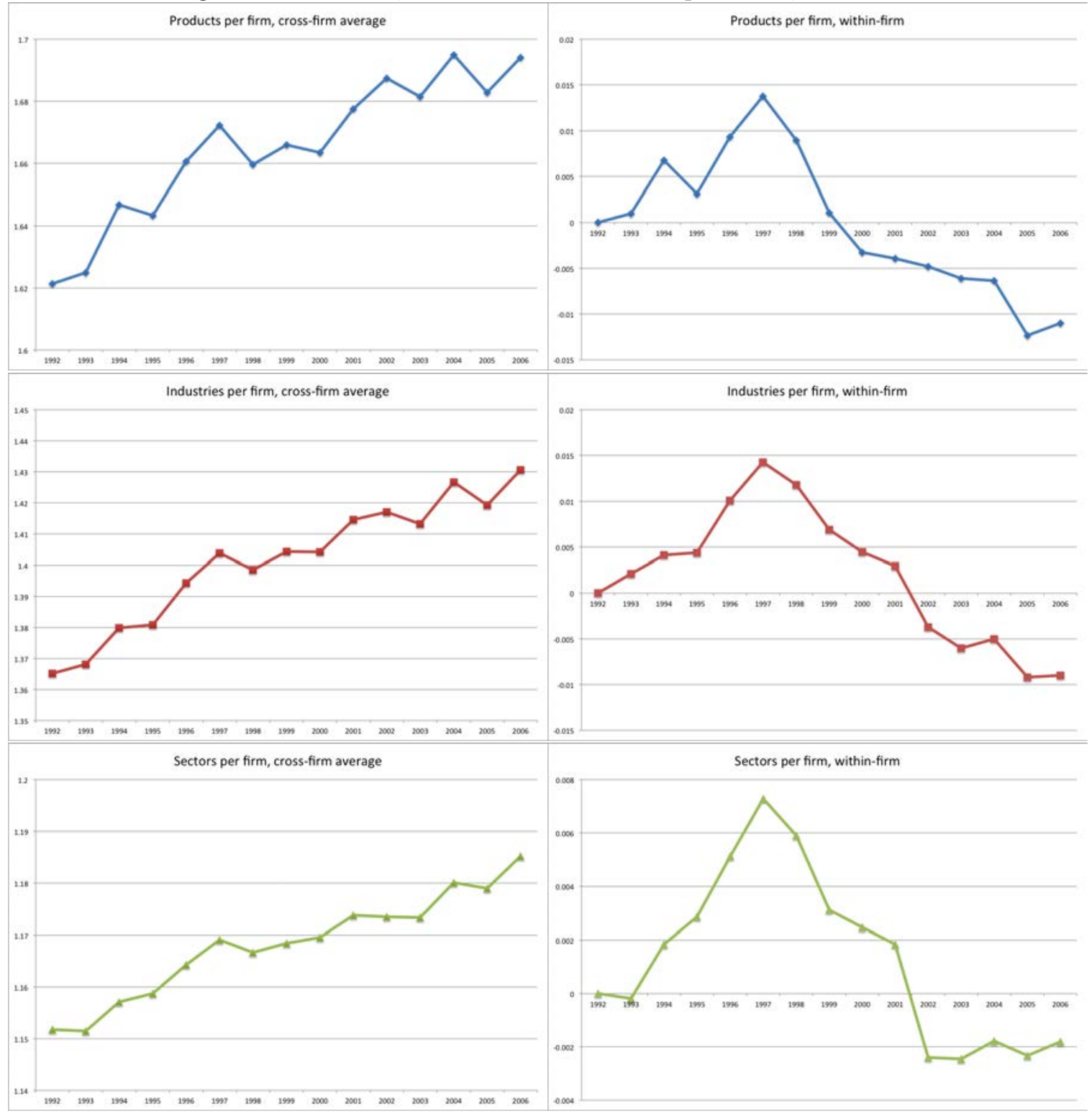

Note: The right-hand set of figures reports the cross-firm averages of products, industries and sectors. The left-hand figures report within-firm changes in products, industries, and sectors per firm; 1992 is the base. 


\subsection{Characteristics}

Mulit-product and multi-industry firms are significantly different in terms of employment, output, exports, and productivity (value-added per employee and revenue TFP). For 2006, we run a regression of the (log of the) characteristic on separate dummies for firms with multiple products, multiple industries and multiple sectors,

$$
\ln X_{p t}=\alpha+\delta_{m p}+\delta_{m i}+\delta_{m s}+\delta_{i}+\varepsilon_{p t}
$$

where $\ln X_{p t}$ is the log of the characteristic for firm $p$ in year $t, \delta_{m p}, \delta_{m i}$, and $\delta_{m s}$ are dummies that equal one if the firm produces multiple products, multiple industries or multiple sectors respectively and $\delta_{i}$ is a set of industry dummies. Table 5 contains the results. As expected, multiple product firms are significant larger in terms of output and employment than single-product firms. They also have higher productivity in terms of TFPR and, especially, labor productivity and are more likely to export. The second and third columns report the additional difference for firms that are also multi-industry and multi-sector. Again the results are as expected with the largest firms being those that produce in multiple sectors. Productivity is also higher at firms with more complex product mixes.

\subsection{Product Adding and Dropping}

Continuing firms change their product mix over time. Unlike Bernard et al. (2010) who have product-level information at 5-year intervals, we are able to look at annual product adding and dropping activity at firms. Table 6 reports on four types of mutually exclusive activity within firms over time. Firms can either do no switching (None), i.e. leave their product mix unchanged from one year to the next, drop one or more products without adding a product (Drop only), add one or more products without dropping a product (Add only), or both add and drop at least one product (Both) $!^{5}$

The large majority of firms (80 percent) do not change their product mix in any given year. When firms do adjust their product mix they are most likely to both add and drop products at the same time (11 percent). Drop only and Add only are much less common activities, 5 and 4 percent respectively. Multi-product firms do more product switching than do single-product firms, in large part due to their ability to Drop only. However MP firms are also twice as likely to churn their product mix by both adding and dropping products from one year to the next. These results suggest a dynamic and active margin of adjustment within the firm. One fifth of firms change their product mix each year, and the share of product switchers rises to one third among multi-product firms.

\footnotetext{
${ }^{5}$ Of course SP firms cannot Drop only as this would leave them with no products.
} 
The bottom panel of Table 6 weights firms by total output and recalculates the shares across the switching types. SP firms that both add and drop are smaller than average while MP firms that do any type of product switching are substantially larger than average. Given the size advantage of MP firms overall, this result points out the importance of MP firm product switching in aggregate manufacturing activity.

The right-hand panel of Table 6 breaks out the product switching behavior during the three pairs of recession transition years. There are significant differences for all types of firms. While Drop only and Add only rates are slightly higher for both SP and MP firms, the biggest changes can be found in the share of firms that are both adding and dropping products. Surviving firms are more likely to churn their product mix in these recession years, 19 percent versus 15 percent in nonrecession years. The output-weighted measure shows an even bigger difference, firms accounting for 24 percent of manufacturing output adjust their product mix by both adding and dropping products during recessions.

\subsection{Industry and sector switching}

We observe similar switching behavior with respect to even more aggregate four-digit JSIC industries and two-digit JSIC sectors. Table 7 documents the extent to which multi-product firms switch across industries or sectors when they change their product mix. The top panel reports on average annual changes at multi-product firms for 1992-2006. Three quarters of MP firms that change their product mix each year are also changing their industry mix, primarily through the simultaneous adding and dropping of industries. Of those firms, more than half (14 percent) are also switching their mix of sectors. The addition of activity in new industries and sectors typically involves substantial differences in production techniques and potentially represents a major change in the activity of the firm. The bottom panel shows that larger firms are more likely to be adjusting their product, industry and sector mixes.

The right hand panel panel reports the same set of numbers for the three recession years. Industry and sector switching is more common during these periods. In particular, the simultaneous adding and dropping of industries (sectors) at the largest firms occurs more often during recession transitions than during other periods.

\section{Products}

We now shift our perspective to examine how changes in product mix by firms are reflected in the distribution of output of a product over time and across firms. 
Figure 4: Add and Drop Rates Across Products

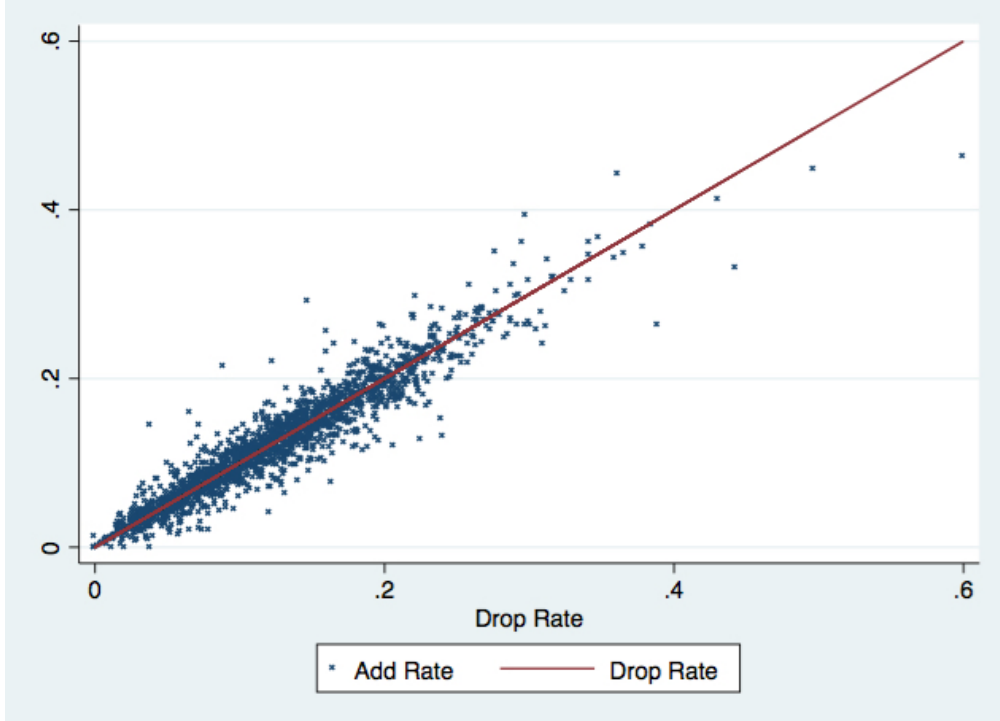

Note: Each point represents the average annual add rate for a product plotted against the average annual drop rate. The 45 degree line indicates where the add rate equals the drop rate. Only products produced at 10 or more firms are included (1765 products).

\subsection{Adding and dropping rates}

One possible explanation for product adding and dropping within surviving manufacturing firms is the secular shift of production away from some products and industries and the growth of others. Figure 4 plots the product-level add rates against drop rates for all 1765 products produced by 10 or more firms. Products above the 45 degree line are, on net, being added by Japanese manufacturing firms while products plotted below the 45 degree line are being dropped. Across products, add and drop rates strongly covary; products that are being added by many firms are the same products that are being dropped by many other firms. There are some products that are, on net, being added and others that are being dropped. However, the rates are tightly clustered along the 45 degree line which suggests that the add and drop rates for a given product are being driven by the same underlying factors. The main determinants of the covariation of add and drop rates across products are usually thought to be related to variation in product-level sunk costs.

\subsection{Product add and drop rates over the cycle}

To understand how product-level add and drop rates move over the cycles we plot the kernel density of add and drop rates for recession and non-recession years in Figure 5 . There is a clear rightward shift of the density for both product adding and product dropping during the recession transition years. In addition the number of products with either no firms adding or no firms dropping is also attenuated during the recession periods. The increase in the add and drop rates is substantial. 
Figure 5: Product Add and Drop Rates over the Business Cycle
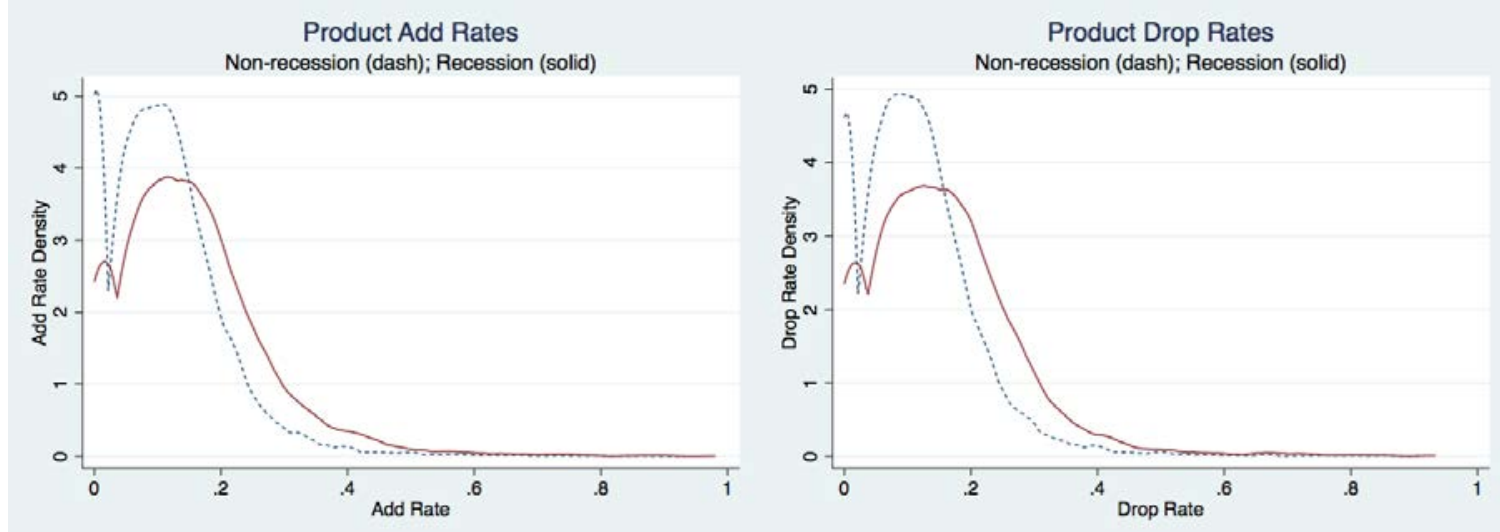

Note: Kernel density estimates of add rates (left) and drop rates (right) for non-recession and recession year. Recession years are 1993-1994, 1998-1999, and 2001-2002. Only products produced at 10 or more firms are included (1765 products).

The drop rate for the average product is 4.2 percentage points higher in recession years relative to non-recession years, an increase of 37 percent. Similarly the add rate for the average product increases by 4.3 percentage points or 38 percent. Of the 1765 products, 1558 ( 88 percent) have an increase in the dropping rate and 1549 have an increase in the adding rate during recessions. 1372 (77 percent) have increases in both adding and dropping rates relative to non-recession years.

While most products see increases in both add and drop rates during the recession years, there remains substantial heterogeneity in the magnitude of the rise across products. We check for systematic differences in the changes in drop/add rates across types of products. We proxy for the sunk costs of adding a product by using a measure based on the minimum of the adding and dropping rates for the product in non-recession years ${ }^{6}$ Products with higher entry sunk costs should show systematically lower adding and dropping rates in all years.

We regress the percentage increase in average product drop (add) rates for recession years relative to non-recession years on the measure of product sunk entry cost,

$$
\frac{\text { Drop Rate }_{p}^{R}}{\text { Drop Rate }_{p}^{N R}}=\alpha+\text { SunkCost }_{p}+\varepsilon_{p} .
$$

The results are shown in Table 8. Both the Add Rate Ratio and the Drop Rate Ratio are positively related to the measure of product sunk costs. Products with typically lower entry rates, i.e. higher sunk costs, see bigger increases in both add rates and drop rates during recession years. Looking across products, we find that moving from the product at the 25 th percentile of sunk costs to that at the 75 th percentile increases the average annual add rate by 1.5 percent and increases the average annual drop rate by 1.3 percent.

\footnotetext{
${ }^{6}$ See Bernard and Jensen $(2007)$.
} 


\subsection{Decomposing product sales across types of firms}

Still considering product-level activity, we focus on how a product's activity is distributed across types of firms. In particular, we report the share of firms adding and dropping a product as well as the share of product output at adding and dropping firms in Table 9. The top panel reports unweighted annual averages across all products in all years while the bottom panel report annual averages across all products for the three recession years. The left-hand columns give information about firms that produce a product today and what those firms were doing in the previous year. Of firms that produce a product in year t, 83 percent also produced the product in the previous year. 12 percent of today's producers existed in the previous period and added the product to their mix, while a much smaller fraction, 5 percent, of today's producers are altogether new firms, i.e. firms that did not produce anything in the previous year. The forward looking shares are similar. On average 80 percent of today's producers will continue to make a product in year $\mathrm{t}+1$, while 12 percent will continue to operate but drop the product from their portfolio and 7 percent will cease operations. These results emphasize the importance of within-firm product additions and deletions relative to firm entry and exit.

The bottom row of the panel does the same decomposition for output. Firms that made the product last year and continue to make it account for 90 of the average product's output across the period. Firms that added the product and new firms producing the product are smaller than continuing firms and account for 6 and 3 percent of output in year t.7 The forward looking decomposition is similar, firms that will no longer make the product and firms that will cease operations are smaller than continuing producers. As expected, the preponderance of product output is at firms that continue to make the product. However, surviving firms that switch into or out of the product are relatively more important than new or exiting firms. This margin of adjustment inside the firm plays a key role in the evolution of product output.

The bottom panel reports the same decomposition for the three recession years. We find that the importance of within-firm product adding and dropping is more pronounced in the recession periods. In the year following a recession, 15.7 percent of firms making a product are surviving firms that newly introduced the product to their portfolio. In contrast both continuing producers and new firms play a smaller role in these periods. In addition the output share at these continuing firms is proportionately greater in the recession periods. The results for product dropping are similar.

\footnotetext{
${ }^{7}$ The output shares of new producers, both continuing firms and new firms, are biased downwards due to the fact that new products and new firms are in the market for less than a full year. Similarly exiting firms and dropped products are also in the market for less than a full year. Measuring the contribution of a full year's sales of new producers on the output share raises the contributions of both types of firms. Bernard et al. (2015) report 40+ percent increases in such shares when correcting for partial-year bias.
} 


\subsection{Decomposing firm output across types of products}

We switch our perspective to analyze the contributions of different types of products to the total output of continuing firms and again perform backward and forward looking decompositions 8 The backward decomposition divides current period output into the share from products produced by the firm in the previous year and the share from new products. The forward decomposition divides the firm's output in the current year into the share in products that will continue to be produced in the next period and the share in products that will be dropped from the product mix in the next period.

Table 10 shows the results of these decompositions for all continuing firms. The top row reports unweighted annual averages across all years while the bottom row reports unweighted averages across the three recession transitions. The left-hand columns give information about the backward decomposition while the right-hand panels perform the forward looking decomposition. Of today's output mix, 93 percent is in products that were produced last year (or products that will continue to be produced next year) while 7 percent of firm output is in products that are new to the firm (or will be dropped form the output mix) 9 Again we find a noticeable difference in the role of product entry and exit in recession years. Added products contribute 9.1 percent of output in the first year after a recession, compared to 6.1 percent in non-recession years. To-be-dropped products are also more important in a firm's output mix for the recession years relative to non-recession years.

\section{Contributions to aggregate output}

We now turn our attention to the contribution of within-firm product adding and dropping to overall output growth in the manufacturing sector. Table 11 decomposes average annual manufacturing output growth from 1992-2006 into extensive and intensive margins ${ }^{10}$ The two extensive margins are the net entry of new firms and the net addition of new products at continuing firms. The intensive margin is the net growth of output at continuing products at continuing firms.

Each column decomposes total output change from one year to the next into the gross and net contributions of the three margins. As show in the last column, average annual output growth in manufacturing over the period was 0.8 percent. As is typically the case, the net intensive margin contributes most of the total, 1.43 percent, while net firm entry was a negligible contributor to output changes 11 The within-firm product margin was negative which is not surprising given the

\footnotetext{
${ }^{8}$ Here we limit our attention to firms that survive from a previous period to the current period or from the current period to the next.

${ }^{9}$ Partial year effects will bias down the roles of new and dropped products in the output share.

${ }^{10}$ The output growth decomposition is performed on nominal output as product-level price indices are not available. Given the near zero change in aggregate prices during the period there is less of a need for deflation of output over time. A concern remains that there is a systematical relationship between growing products, or products at growing firms, and relative prices changes.

${ }^{11}$ As discussed above, measuring the contribution of a full year's sales of new products to output growth over a 12
} 
finding of a reduction in the number of products within firms over the period. Of perhaps greater interest is the relative size of the gross contributions of the two extensive margins. The new product entry margin is larger than the new firm entry margin and the product exit margin at continuing firms is also larger than the firm exit margin. The reallocation inside firms is as large or larger than the reallocation across firms that is the typical focus of the literature.

Table 11 highlights the recession transition years in bold (and red). We find that the large increases in product adding and dropping documented across products and firms show up in the aggregate output numbers as well. Output growth due to product entry by continuing firms rises from 2.62 percent per year in non-recession years to 4.3 percent in recession years. Similarly the contribution of product dropping rises from 3.15 to 5.24 percent. The intensive margin effects of continuing products is lower during these transition periods, exacerbating the relative contribution of within firm reallocation.

\section{$7 \quad$ A "trapped factors" explanation}

We find strong evidence that the product switching behavior of firms is quantitatively important and changes systematically over the business cycle. The transition from the last year of a recession to the first year of the subsequent expansion is a time of substantial changes in firm product mix for continuing firms. More firms churn their product mix by both adding new products and dropping existing products. In addition, firms are more likely to add and drop industries and sectors during recession transitions. This change in activity is not limited to a few products, more than three quarters of products see an increase in add and drop rates and this increase is greater for products with higher sunk costs of entry. New production at continuing firms is a greater share of output as is the share of production in products that will be dropped. New products represent a greater share of both aggregate and firm output over the recession transition years.

The theoretical literature on firm-level product switching is relatively small ${ }^{12}$ Bernard et al. (2010) present a dynamic model of steady state product adding and dropping. More productive firms have more products and thus are more likely to both add and drop products. However, in that model, changes to firm productivity produce asymmetric effects on within-firm product adding and dropping. An increase in firm productivity will lead to more product adding relative to product dropping. Our empirical results suggest that recessions are a time of increased adding and dropping for firms.

Bilbiie et al. (2012) model endogenous producer entry and creation of new products over the business cycle. While their framework has single-product firms and thus confounds product entry

month period would raise the gross margins (both entry and exit) but has an uncertain effect on the net contributions.

${ }^{12}$ Most recent models of multi-product exporters are static, e.g. Eckel and Neary (2010); Bernard et al. (2011); Mayer et al. (2014) 
with firm entry, it is motivated by the new empirical literature on multi-product firms and product switching. We highlight important differences between product introductions by existing firms and the entry of new firms over the business cycle. In Bilbiie et al. (2012), product creation requires sunk product development costs and in equilibrium they find that product creation is pro-cyclical, a feature of the data confirmed by our results. However, the strong difference between within-firm and new firm product creation points to an important distinction between new products introduced by existing firms and those created by new entrants.

Our results suggest that the costs of entering new products for continuing firms fall precisely over the bottom of the business cycle and that this change is widespread across firms and products. This type of change is analogous to a systemic reduction in the sunk costs of product entry for continuing firms without a similar cost reduction for potential new entrants. We suggest a version of the "trapped factors" model found in Bloom et al. (2013) and Bloom et al. (2014) as a likely explanation for our findings.

The essence of the trapped factors model is that a negative demand shock reduces the use of labor in production activities. The labor that is freed from production is then available for the firm to use in innovation or in the creation of new products. The trapped nature of the labor input in the firm reduces the opportunity cost of product creation when demand is low and increases the rate of product adding from the end of the recession to the beginning of the expansion. Product dropping increases in the same period because of the negative demand shock itself, some existing products are no longer profitable.

Bloom et al. (2014) focus on the negative demand shock emanating from China's export surge following accession to the WTO and examining innovation activities in the subsequent period. In our case the negative demand shock is the recession itself, and the counterpart to rise of innovation is the increase in product churning within the firm. We find this explanation particularly appealing in the case of Japan in the 1990's and early part of the 2000's. During this period the practice of lifetime employment was still widespread and thus a large fraction of the workforce would have the characteristic of a "trapped" factor of production. Japanese firms would have had the incentive to redeploy production workers toward product development during the periods of output contraction. In addition, the products most likely to be introduced, and dropped, during such an episode would be those with the greatest costs of entry.

Ideally we would have exogenous industry or firm-level shocks to use to identify the increase in product adding and dropping. In the absence of such exogenous variation, we run firm-level adding and dropping regressions and interact firm characteristics (TFP, log employment and a multi-establishment dummy) with a dummy for the three recession years. Table 12 reports the results for multi-product firms. As expected firm productivity is positively related to the probability of adding a product. Firm size, as measured by log employment, is negatively related to product 
adding. Smaller, more productive firms are more likely to add a product. Recession years show a different pattern. While the recession dummy has the expected, large, positive and significant coefficient, the interaction terms on employment and TFP are positive and negative respectively. Product adding in recession years is more likely to occur at less productive, larger firms.

The results for product dropping reported in column 2 are similar. Product dropping is generally more prevalent at less productive, smaller firms. In recession years, the negative correlation between product dropping and productivity is enhanced while the relationship between firm size and dropping is attenuated. Both the adding and dropping results are suggestive of a trapped factors explanation. Less productive, larger firms have increased probabilities of dropping and adding during recessions. These are precisely the types firms likely to be most exposed to the downturn (lower productivity) and most likely to have unused labor within the firm (larger employment).

\section{Conclusion}

This paper has documented the extent and importance of multi-product firms in the Japanese manufacturing sector. Multi-product firms are larger and more productive than single product firms and their importance increased during a period when Japanese manufacturing output was declining as a share of overall economic activity.

The paper also performs the first analysis of the role of product switching inside existing manufacturing firms over the business cycle. Substantial research has focused on the entry and exit of firms and firms and their role in industrial dynamics, employment creation and output growth. In that work, new producers of a product are synonymous with entering firms, while in reality most new producers of a product are continuing firms. Far less attention has considered the role of product mix changes within continuing firms. This research provide the first evidence of the importance of annual product adjustments within manufacturing firms in a major industrialized country. Twenty percent of continuing firms adjust their product mix every year with that share rising to a third of multi-product firms. The within-firm margin of adjustment is as important, or more important, than the extensive margin of new or failing firms.

We find large differences in the rate of product switching over the business cycle. Product adding and dropping increases between the last year of a downturn and the first year of the subsequent expansion. Across firms we find that there a simultaneous increase in dropping and adding and that the effects are largest for firms with the greatest sunk cost of entry. This increase in product switching is not mirrored by an increase in entry and exit rates of new firms. The active margin in these recession years is within continuing firms.

The most plausible explanation for this increased activity within firms comes from the recent papers by Bloom et al $(2013,2014)$ on trapped factors and product innovation. During recessions, Japanese manufacturing firms redeploy workers from production to innovation or product 
development leading to an increase in product introductions in the following year.

While this paper describes the mix of products and firms in the Japanese manufacturing sector over the business cycle, there remain important unanswered questions for future research. An important area of further investigation is how tight credit conditions in the financial markets affect innovation activities at different types of firms. 


\section{References}

Baily, Martin N., Charles Hulten, and David Campbell, "Productivity Dynamics in Manufacturing Establishments," Brookings Papers on Economic Activity: Microeconomics, 1992, 4, 187-249. 1

Bernard, Andrew B. and J. Bradford Jensen, "Firm Structure, Multinationals, and Manufacturing Plant Deaths," Review of Economics and Statistics, May 2007, 89 (2), 193-204. 6

_ , Renzo Massari, Jose-Daniel Reyes, and Daria Taglioni, "Exporter Dynamics and Partial Year Effects," Working Paper, Tuck School of Business 2015. 7

_ , Stephen J. Redding, and Peter K. Schott, "Multiple-Product Firms and Product Switching," American Economic Review, March 2010, 100 (1), 70-97. 1, 4, 4.4. 7

_ , _, and _, "Multiproduct Firms and Trade Liberalization," The Quarterly Journal of Economics, 2011, 126 (3), 1271-1318. 1, 4.2, 12

Bilbiie, F. O., F. Ghironi, and M. J. Melitz, "Endogenous Entry, Product Variety, and Business Cycles," Journal of Political Economy, April 2012, 120 (2), 304-345. 7

Bloom, Nicholas, Paul M. Romer, Stephen J. Terry, and John van Reenen, "A TrappedFactors Model of Innovation," American Economic Review Papers and Proceedings, May 2013. 1. 7

_ , _ , _ and _ , "Trapped Factors and China's Impact on Global Growth," Working Paper 19951, NBER March 2014. 1, 7

Caballero, Ricardo J., Takeo Hoshi, and Anil K Kashyap, "Zombie Lending and Depressed Restructuring in Japan," American Economic Review, December 2008, 98 (5), 1943-1977. 1

Campbell, Jeffrey R., "Entry, exit, embodied technology and business cycles," Review of Economic Dynamics, 1998, 1, 371-408. 3.2

Dunne, Timothy, Mark J Roberts, and Larry Samuelson, "The Growth and Failure of U.S. Manufacturing Plants," The Quarterly Journal of Economics, November 1989, 104 (4), 671-98. 1 .

_, Mark J. Roberts, and Larry Samuelson, "Plant Turnover and Gross Employment Flows in the U.S. Manufacturing Sector," Journal of Labor Economics, January 1989, 7 (1), 48-71. 1

Eckel, Carsten and Peter Neary, "Multi-product firms and flexible manufacturing in the global economy," Review of Economic Studies, 2010, 77 (1), 188-217. 4.2, 12 
Foster, Lucia, John Haltiwanger, and C.J. Krizan, "Market selection, reallocation and restructuring in the U.S. retail trade sector in the 1990's," The Review of Economics and Statistics, 2006, 88 (4), 748-758. 1

Fukao, Kyoji and Hyeog Ug Kwon, "Why did Japan's TFP Growth Slow Down in the Lost Decade? An Empirical Analysis Based on Firm-Level Data of Manufacturing Firms," Japanese Economic Review, 2006, 57, 195-228. 1

Goldberg, Pinelopi K., Amit K. Khandelwal, Nina Pavcnik, and Petia Topalova, "Imported Intermediate Inputs and Domestic Product Growth: Evidence from India," The Quarterly Journal of Economics, 2010, 125 (4), 1727-1767. 1

Iacovone, Leonardo and Beata Javorcik, "Multi-product Exporters: Product Churning, Uncertainty and Export Discoveries," Economic Journal, 2010, 120(544). 1

Kawakami, Atushi and Tsutomu Miyagawa, "Product Switching and Firm Performance in Japan," Discussion Paper 10043, RIETI September 2010. 1

Mayer, Thierry, Marc J. Melitz, and Gianmarco I.P. Ottaviano, "Market Size, Competition, and the Product Mix of Exporters," American Economic Review, April 2014, 104(2) (16959). 4.2. 12

Nishimura, Kiyohiko G., Takanobu Nakajima, and Kozo Kiyota, "Does the Natural Selection Mechanism Still work in Severe Recessions? - Examination of the Japanese Economy in the 1990s," Journal of Economic Behavior E Organization, 2005, 58 (1), 53-78. 1

Pierce, Justin R. and Peter K. Schott, "Concording US Harmonized System Categories over Time," Journal of Official Statistics, 2012, 28 (1), 53-68. 2 
Table 2: Industries and Products by Sector

\begin{tabular}{|cl|cc|}
\hline Sector & Description & Industries & Products \\
\hline 9 & Food & 41 & 122 \\
10 & Beverages, Tobacco and Feed & 13 & 33 \\
11 & Textile & 63 & 235 \\
12 & Lumber and Wood products & 17 & 52 \\
13 & Furniture and fixtures & 15 & 29 \\
14 & Pulp and paper products & 7 & 63 \\
15 & Printing & 38 & 18 \\
16 & Chemical & 5 & 205 \\
17 & Petroleum and coal products & 25 & 61 \\
18 & Plastic products & 13 & 53 \\
19 & Rubber products & 10 & 45 \\
20 & Leather tanning, leather products and fur skins & 44 & 143 \\
21 & Ceramic, stone and clay products & 23 & 86 \\
22 & Iron and steel & 17 & 64 \\
23 & Non-ferrous metals and products & 33 & 135 \\
24 & Fabricated metal products & 19 & 92 \\
25 & General machinery & 25 & 148 \\
26 & Production machinery & 22 & 80 \\
27 & Business oriented machinery & 12 & 23 \\
28 & Electronic parts, devices and electronic circuits & 22 & 99 \\
29 & Electrical machinery & 12 & 42 \\
30 & Information and communication electronics equip. & 16 & 83 \\
31 & Transportation equipment & 30 & 120 \\
32 & Other manufacturing & 531 & 2060 \\
\hline & Total & & \\
\hline
\end{tabular}

Note: The table reports the number of four digit industries and six digit products across two-digit manufacturing sectors. 


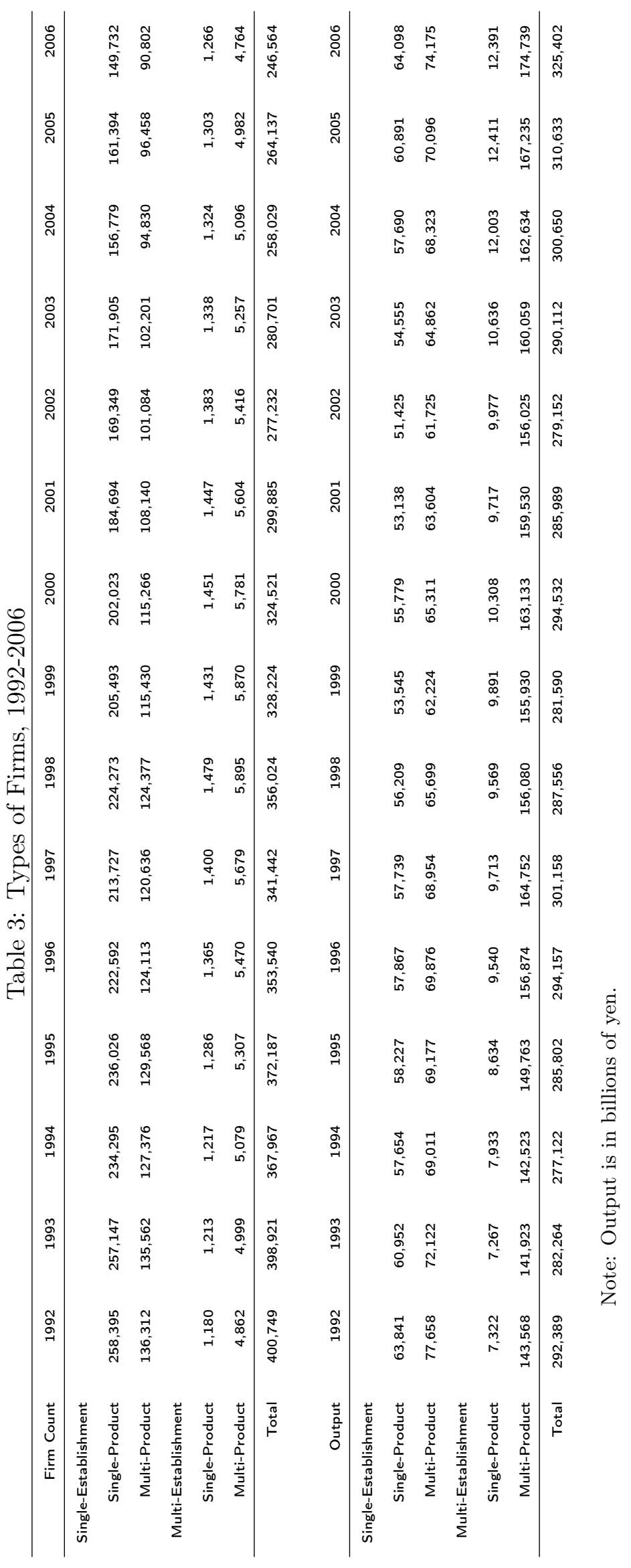


Table 4: Prevalence and Importance of Multi-Product Firms

\begin{tabular}{r|ccc}
\hline & \multicolumn{3}{|c}{1992} \\
& Percent of firms & Percent of output & Products \\
\hline Single product & 64.8 & 24.3 & 1.0 \\
Multi-product & 35.2 & 75.7 & 2.7 \\
Multi-industry & 24.7 & 67.7 & 2.9 \\
Multi-sector & 11.7 & 50.1 & 3.1 \\
& & & \\
& & 2006 & \\
& Percent of firms & Percent of output & Products \\
\hline Single product & 61.2 & 23.5 & 1.0 \\
Multi-product & 38.8 & 76.5 & 2.8 \\
Multi-industry & 27.6 & 70.1 & 3.0 \\
Multi-sector & 14.0 & 52.4 & 3.2 \\
\hline
\end{tabular}

Note: The first two columns give the share of firms and output, the third column reports the average number of products for firms in that category. 
Table 5: Characteristics of Multi-Product Firms, 2006

\begin{tabular}{r|ccc}
\hline & Multi-product & Multi-industry & Multi-sector \\
\hline Employment & 0.037 & 0.171 & 0.149 \\
Output & 0.235 & 0.194 & 0.262 \\
Exporter & 0.010 & 0.003 & 0.013 \\
TFP & 0.110 & 0.013 & 0.053 \\
Value-added per worker & 0.161 & 0.197 & 0.281 \\
\hline
\end{tabular}

Note: Each row represents a regression with multi-product, multi-industry and multisector dummies including primary industry fixed effects. The coefficients represent the difference between that type of firm and the type in the column to the left where the base type is single-product (and thus single industry and single sector). All dependent variables are in logs and all regressions are OLS except for the Exporter specification which reports the marginal effects of a probit on an export dummy for the firm. All coefficients are significant at the 5 percent level. 
Table 6: Annual Product Adding and Dropping

\begin{tabular}{r|ccc|ccc}
\hline & \multicolumn{3}{|c|}{ All years } & \multicolumn{4}{c}{ Recession years } \\
\hline & All firms & SP & MP & All firms & SP & MP \\
Percent of firms & & & & & & \\
None & 80 & 88 & 67 & 77 & 86 & 62 \\
Drop only & 5 & - & 13 & 5 & 0 & 14 \\
Add only & 4 & 4 & 5 & 5 & 5 & 5 \\
Both & 11 & 8 & 16 & 13 & 10 & 19 \\
\hline & & & & & & \\
Percent of output & & & & & & \\
None & 64 & 91 & 56 & 61 & 88 & 53 \\
Drop only & 11 & - & 14 & 10 & 0 & 13 \\
Add only & 8 & 5 & 9 & 9 & 6 & 10 \\
Both & 16 & 4 & 20 & 20 & 6 & 24 \\
\hline
\end{tabular}

Note: The numbers indicate the annual average share of surviving firms of different types involved in product adding and dropping between 19932006. The top panel gives the share of firms, the bottom panel given the output-weighted share. The three recession intervals are 1993-1994, 1998-1999, and 2001-2002. 
Table 7: Product, Industry and Sector Switching

\begin{tabular}{r|ccc|ccc}
\hline & \multicolumn{3}{|c|}{ All years } & \multicolumn{3}{c}{ Recession years } \\
Firm share & Product & Industry & Sector & Product & Industry & Sector \\
\hline None & 67 & 74 & 86 & 62 & 70 & 84 \\
Drop only & 13 & 9 & 4 & 14 & 10 & 4 \\
Add only & 5 & 4 & 3 & 5 & 4 & 2 \\
Both & 16 & 13 & 8 & 19 & 16 & 10 \\
& & & & & & \\
Output share & Product & Industry & Sector & Product & Industry & Sector \\
\hline None & 56 & 58 & 64 & 53 & 54 & 61 \\
Drop only & 14 & 14 & 11 & 13 & 13 & 10 \\
Add only & 9 & 9 & 7 & 10 & 9 & 7 \\
Both & 20 & 20 & 18 & 24 & 23 & 22 \\
\hline
\end{tabular}

Note: The upper panel shows average share of multi-product firms involved in annual product, industry and sector adding and dropping from 1993-2006. The lower panel shows comparable averages for weighted by output. The three recession intervals are 1993-1994, 1998-1999, and 2001-2002. 
Table 8: Product Sunk Costs and Add/Drop Rates in Recessions Add Rate Ratio Drop Rate Ratio

\begin{tabular}{crr}
\hline Sunk Cost & $0.0018^{* * *}$ & $0.0016^{* * *}$ \\
Constant & $1.415^{* * *}$ & $1.379^{* * *}$ \\
& & \\
Obs & 1762 & 1762 \\
$\bar{R}^{2}$ & 0.007 & 0.008 \\
\hline
\end{tabular}

Note: Add Rate Ratio is the ratio of the average annual add rate during recession years to the average annual add rate during non-recession years for the product. Drop Rate Ratio is defined similarly for product drop rates. The three recession periods are 1993-1994, 1998-1999, 2001-2002. The sunk cost measure is the inverse of the minimum of the average annual add rate and the average annual drop rate for the product during non-recession years. ${ }^{* * *}$ indicates significance at the $1 \%$ level. 


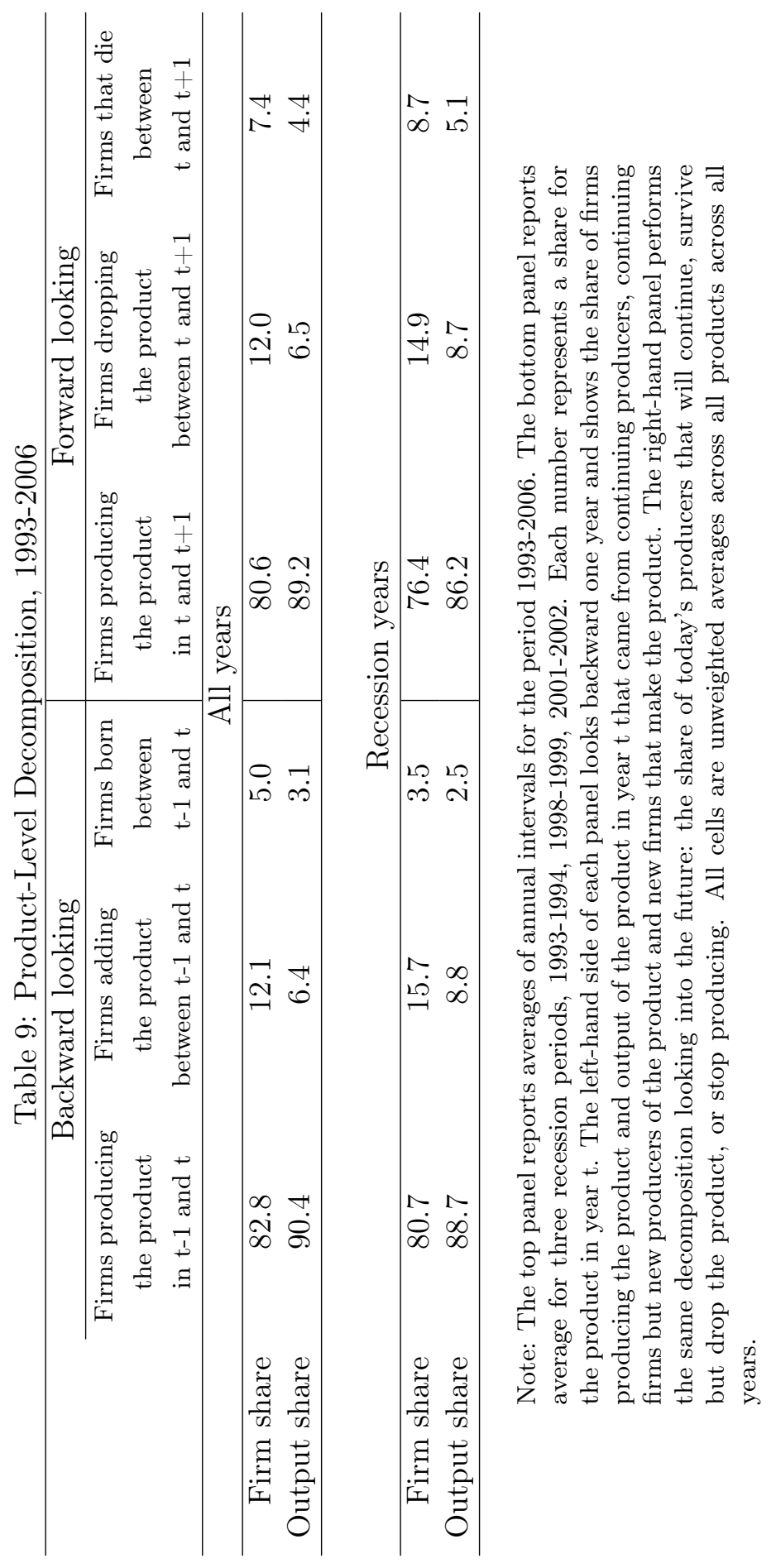


Table 10: Firm Output Decomposition

\begin{tabular}{r|cccc}
\hline & \multicolumn{2}{|c}{ Backward } & \multicolumn{2}{c}{ Forward } \\
\cline { 2 - 5 } & Continuing & Added & Continuing & Dropped \\
\hline All years & 93.4 & 6.7 & 93.3 & 6.9 \\
Recession years & 91.1 & 9.1 & 90.5 & 9.6 \\
\hline
\end{tabular}

Note: The left two columns of each panel give the (continuing) firm output share from previously produced product and products added in the last year. The right two columns of each panel give the (continuing) firm output share in products that will still be produced the next year and in products that will be dropped in the next year. The three recession intervals are 1993-1994, 1998-1999, and 2001-2002. All numbers are unweighted averages across all continuing firms. 


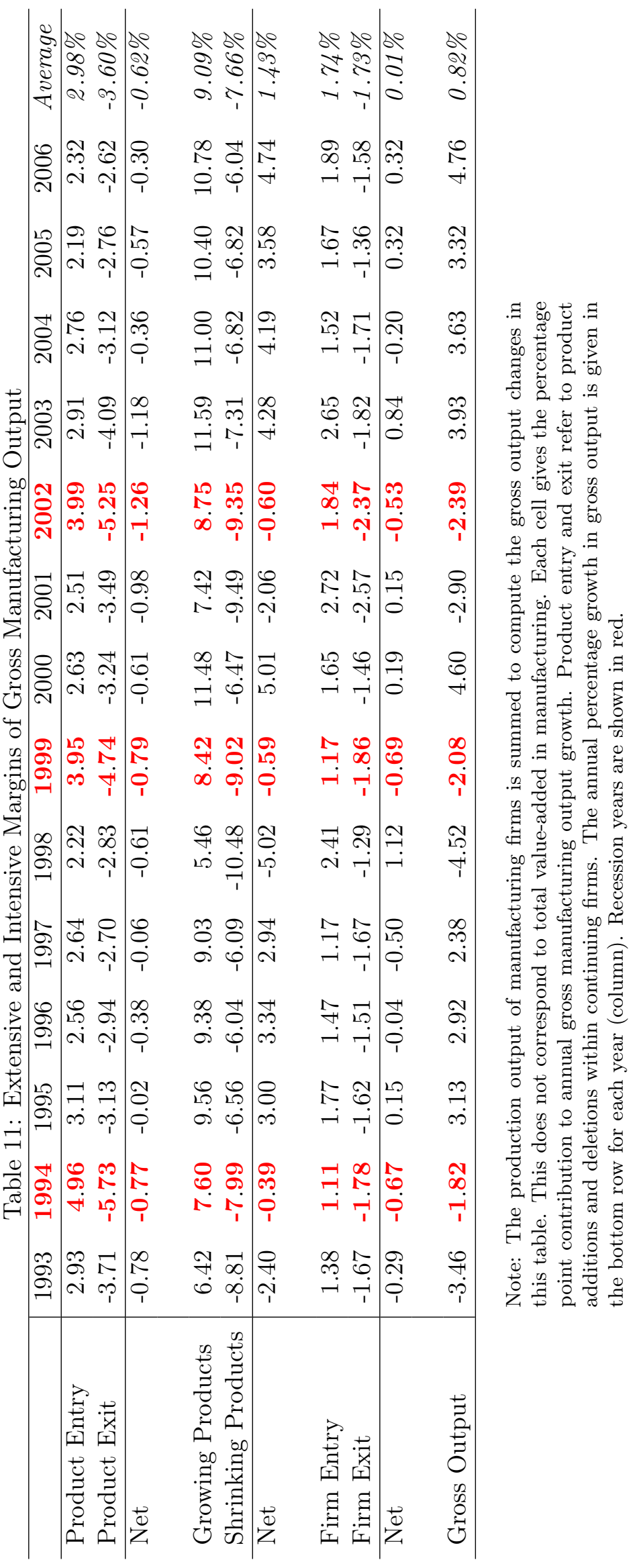


Table 12: Firm-level Product Adding and Dropping

\begin{tabular}{|c|c|c|}
\hline & Adding & Dropping \\
\hline$\overline{\mathrm{TFPR}}$ & $0.0022^{* * *}$ & $\begin{array}{l}-0.0066^{* * *} \\
(00006)\end{array}$ \\
\hline log Employment & $\begin{array}{l}-0.0333^{* * *} \\
(0.0005)\end{array}$ & $\begin{array}{l}-0.0271^{* * *} \\
(0.0005)\end{array}$ \\
\hline Multi-Establishment & $\begin{array}{l}0.0006^{* * *} \\
(0.0027)\end{array}$ & $\begin{array}{l}0.0284^{* * *} \\
(0.0028)\end{array}$ \\
\hline Recession & $\begin{array}{l}0.1189^{* * *} \\
(0.0067)\end{array}$ & $\begin{array}{l}0.0552^{* * *} \\
(0.0065)\end{array}$ \\
\hline$\times \mathrm{TFPR}$ & $\begin{array}{l}-0.0037^{* * *} \\
(0.0011)\end{array}$ & $\begin{array}{l}-0.0019^{*} \\
(0.0011)\end{array}$ \\
\hline$\times \log$ Employment & $\begin{array}{l}0.0027^{* * *} \\
(0.0009)\end{array}$ & $\begin{array}{l}0.0111^{* * *} \\
(0.0009)\end{array}$ \\
\hline$\times$ Multi-Estab & $\begin{array}{r}0.0001 \\
(0.0045)\end{array}$ & $\begin{array}{r}-0.0020 \\
(0.0044)\end{array}$ \\
\hline $\begin{array}{l}\text { Fixed Effects } \\
\bar{R}^{2} \\
\text { Observations }\end{array}$ & $\begin{array}{c}\text { Industry } \\
0.190 \\
1,788,667\end{array}$ & $\begin{array}{c}\text { Industry } \\
0.218 \\
1,556,828\end{array}$ \\
\hline
\end{tabular}

Note: $* * *, * *, *$ indicate significance at the 1,5 , and 10 percent levels respectively. 